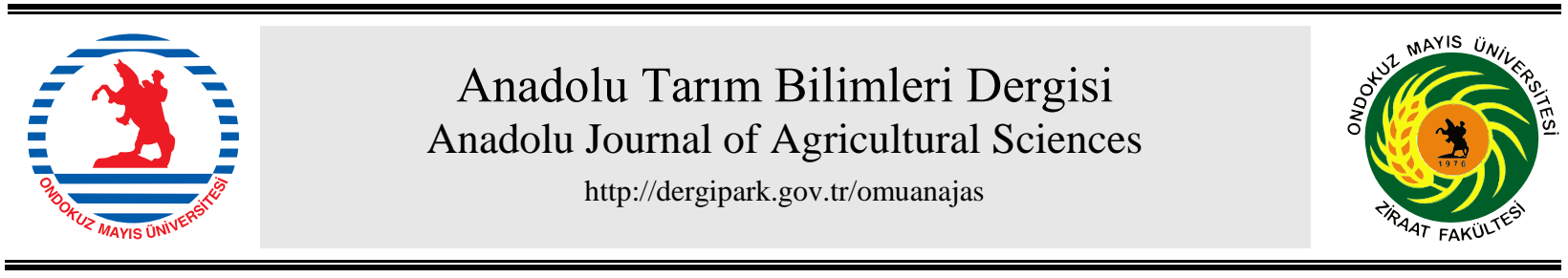

Araştırma/Research

Anadolu Tarım Bilim. Derg./Anadolu J Agr Sci, 36 (2021)

ISSN: 1308-8750 (Print) 1308-8769 (Online)

doi: 10.7161/omuanajas.932318

\title{
Siyah Alaca ineklerde diş görünüş özellikleri ile süt ve döl verim özellikleri arasındaki genetik ilişkiler
}

\author{
Ramazan Erkmen ${ }^{\mathrm{a}}$, $\odot$ Ertuğrul Kul ${ }^{\mathrm{a}}$ \\ ${ }^{a}$ Kırşehir Ahi Evran Üniversitesi, Ziraat Fakültesi, Zootekni Bölümü, Kırşehir, Türkiye
}

*Sorumlu yazar/corresponding author: ertugrul.kul@ ahievran.edu.tr

Geliş/Received 03/05/2021 Kabul/Accepted 14/08/2021

\begin{abstract}
ÖZET
$\mathrm{Bu}$ araştırma, Kırşehir ilinde özel bir süt sı̆̆ırı işletmesinden yetiştirilen 230 baş Siyah Alaca ineğinin dış görünüş özelliklerine ait bazı parametrelerin tahmin edilmesi ve bu özellikler ile süt ve döl verim özellikleri arasındaki korelasyonların belirlenmesi amacıyla yapılmıştır. Genetik parametre tahmini için BLUP Hayvan Modeli'ni (Animal Model, birey modeli) esas alan MTDFREML programından yararlanılmıştır. Dış görünüş özellikleri için kalıtım dereceleri 0.07 ile 0.44 arasında hesaplanmıştır. Genel olarak, sütçülük özelliği için orta, beden özellikleri için düşük-orta, ayak ve bacak özellikleri için düşük, meme özellikleri için ise orta-yüksek düzeyde kalıtım dereceleri hesaplanmıştır. Süt (305-gSV) ve döl verim özellikleri (BİTAS, SP ve BA) için kalıtım dereceleri ise 0.05 ile 0.18 arasındadır. Dış görünüş özellikleri ile süt ve döl verim özellikleri arasındaki genetik korelasyonlar sırasıyla -0.90 ile 0.96 ve -0.33 ile 0.61 arasında hesaplanmıştır. Süt ve döl verim özellikleri ile dış görünüş özellikleri arasındaki fenotipik korelasyonlar ise düşük düzeyde ve -0.25 ile 0.25 arasında belirlenmiştir. Elde edilen sonuçlar, yüksek sağrılı, narin sütçülük özelliğinde, geniş göğüslü, derin bedenli, alçalan ve geniş sağrılı, dik arka ayak açılı, kuru arka diz yapısı, yüksek arka memeli ve toplam puan bakımından daha iyi damızlık vasfı taşıyan ineklerin daha yüksek süt verimine sahip olduğunu göstermiştir. Dar gögüslü, sığ bedenli, dar sağrılı ve zayıf bir meme bağlantısına sahip inekler ise daha kısa bir BİTAS'ye sahiptir. Bu sonuçlar, Siyah Alaca ineklerde bu özelliklerin süt ve döl verim performansının iyileştirilmesinde dolaylı seleksiyon kriteri olarak kullanılabileceğini göstermiştir.
\end{abstract}

Genetic relationships between type traits with milk yield and reproductive traits in Holstein Cows

\section{ABSTRACT}

This research was carried out to estimate some parameters of type traits of 230 head Holstein cows raised in private dairy cattle enterprise in Kırşehir and determine the correlations between these type traits with milk yield and reproductive characteristics. Estimates of genetic parameters were obtained from MTDFREML software based on BLUP Animal Model (Animal Model, individual model). The heritability for the type traits were calculated from 0.07 to 0.44 . Medium heritability for dairy character, low-medium for body conformation traits, low for feet and legs traits, and medium-high for udder traits were generally calculated. The heritability for milk yield (305-dMY) and reproductive traits (CFSI, DO and CI) were varied from 0.05 to 0.18 . Genetic correlations between type traits with milk yield and reproductive traits were calculated from -0.90 to 0.96 and -0.33 to 0.61 , respectively. The phenotypic correlations between milk and reproductive traits with type traits were determined low level and ranging from -0.25 to 0.25 . The results obtained showed that cows with high rump, frailty dairy form, wide strength, deep body depth, descending and wide rump, straight rear legs side view, dry hock status, high rear udder and better breeding characteristics in terms of final score had higher milk yield. Cows with narrow chest with, shallow body depth, narrow rump and weak udder attachment had a shorter CFSI. The results showed that these traits may be used as an indirect selection criterion for improving milk yield and reproduction performance in Holstein cows.
Anahtar Sözcükler: Siyah Alaca Dış görünüş özellikleri Kalıtım derecesi Genetik korelasyon Fenotipik korelasyon

Keywords:

Holstein cow

Conformation traits

Heritability

Genetic correlation

Phenotypic correlation

(C) OMU ANAJAS 2021 


\section{Giriş}

Türkiye hayvan varlığı bakımında dünyada ilk sıralarda yer almasına karşın hayvan başına elde edilen verimler yönünden yeterli düzeyde değildir. Özellikle ülkemizde en önemli et ve süt üretim kaynağı olan sığır başına karkas ve süt üretimi 2019 yılı itibari ile yaklaşık $295 \mathrm{~kg}$ ve $3158 \mathrm{~kg}$ civarındadır (TÜİK, 2021). Ülkemizde sığır başına verim gelişmiş ülkeler ile kıyaslandığında oldukça düşük düzeydedir. Bu durum ülkemizin hala hedeflenen verim seviyesinin çok altında olduğunu ve sığır başına elde edilen süt, et ve döl verimini arttırmak için 1slah çalışmalarına önem verilmesi gerektiğini göstermektedir.

Ekonomik süt sığırı yetiştiriciliğinde süt veriminin önemli olmasının yanı sıra, döl verimi ve uzun ömürlülük, ya da bir ineğin hayatı boyunca yüksek süt verimi ve döl verimine dayanabilecek yapıya sahip olması da önemlidir. Bunun için ineklerin iyi bir soydan gelmelerinin yanı sıra, sağlam ve gelişmiş bir vücut yapısına, kapasiteli bir memeye, ağır bedeni taşıyacak yapıda ayak, tırnak ve bacak yapısına sahip olması gerekir (Çerçi, 2006). Süt sığırlarının daha uzun ömürlü olması ve daha fazla verim vermesi için, damızlık değerlerinin tahmin edilmesinde, verim özellikleriyle birlikte dış görünüş özelliklerinin de dikkate alınması gerekmektedir. Nitekim dış görünüş özelliklerinden yararlanarak, daha yüksek süt, et ve döl verimine sahip, daha dayanıklı ve uzun ömürlü hayvanların elde edilmesinin mümkün olduğu ve bu durumun da karlılığı olumlu yönde etkilediği bildirilmektedir (Yaylak ve Akbaş, 2004). İneklerin yüksek verimin yükünü uzun yıllar boyunca taşıyabilmesi ancak vücutlarının buna uygun bir yapıda olması ile mümkündür (Ermetin, 2007). Bu nedenle doğrusal tip özellikleri olarak da ifade edilen diş görünüş özellikleri sürü yönetimiyle ilgili birçok avantajlar sağlamaktadır (Yaylak ve Akbaş, 2004).

Dünyada 1slah programları süt verimi ile döl verim özellikleri arasındaki negatif ilişki dikkate alınmadan öncelikle süt verim özellikleri üzerinde yoğunlaşmıştır. Döl verim özellikleri genellikle düşük kalıtım derecesine sahiptir olması nedeniyle genetik iyileşmeyi artırabilecek, kalıtım derecesi daha yüksek olan diğer özelliklerin 1slah programlarında dikkate alınması gerekir. Doğrusal tanımlama özellikleri seleksiyon indeksi içerisinde yüksek kalıtım dereceleri nedeniyle en önemli alternatif yöntemler arasında yer almaktadır (Madrid Gaviria ve Echeverri Zuluaga, 2014). Özellikle üreme özelliklerinin düşük kalıtım derecesine sahip olması nedeniyle genetik iyileşme amacıyla ilişkili özelliklerden yararlanılması gerekmektedir (Makgahlela ve ark., 2009). Nitekim özellikle döl verim özellikleri ile dış görünüş özelliklerinin beraber kullanıldığı seleksiyon indeksleri üreme performansının artırılmasına önemli derecede katkı sağlayacaktır (Madrid Gaviria ve Echeverri Zuluaga, 2014).

Bugüne kadar birçok çalışmada, süt verimi, döl verimi ve damızlıkta kullanma süreleri ile dış görünüş özellikleri arasında ilişkiler araştırılmış, dış görünüş özellikleri ile verim özellikleri arasında sahada kullanılabilecek sonuçlar belirlenmiştir. Ancak ülkemizde bu konuda yapılan araştırma sayısı yurtdışında yapılan çalışmalar ile karşılaştırıldığında sınırlı sayıdadır. Bu nedenle süt veriminin arttırılması yönünde yapılacak ıslah çalışmalarında süt verimi ve döl verimi ile ilişkisi olan muhtelif vücut özellikleri üzerinde daha fazla çalışmaya ihtiyaç duyulmaktadır.

$\mathrm{Bu}$ çalışma ile Kırşehir ilinde yetiştiriciliği yapılan Siyah Alaca ineklerde dış görünüş özelliklerine ilişkin kalıtım derecelerinin hesaplanması, ilgili özellikler ile bazı süt ve döl verim özellikleri arasındaki ilişkilerin tespit edilmesi amaçlanmıştır.

\section{Materyal ve Yöntem}

\subsection{Materyal}

Araştırma materyalini Kırşehir ilinde bulunan özel bir süt sığırı işletmesinde Haziran 2017 ve Ocak 2019 tarihleri arasında buzağılayan 51 baba ve 186 anadan doğan $1(n=95), 2(n=48)$ ve $\geq 3$. laktasyonda $(n=87)$ bulunan toplam 230 baş Siyah Alaca inek oluşturmuştur.

\subsection{Yöntem}

\subsubsection{Doğrusal tanımlama özelliklerinin tanımlanması}

Araştırmada doğrusal tanımlama, 1, 2 ve $\geq 3$. laktasyondaki ineklerde laktasyonlarının 30-150. günleri arasında olan ineklerde yapılmıştır. Doğrusal tanımlamada Dünya Holstein Friesian Federasyonu'nun (WHFF) belirlediği 17 özellikten 16'sı dikkate alınmıştır. Bu özelliklerden yalnızca sağrı yüksekliği ölçü bastonundan yararlanılarak cm biriminden belirlenmiştir. Diğer özellikler 1-9 puanlama cetveline göre değerlendirilmiştir (Duru, 2005; Çerçi, 2006; Anonymous, 2018). 


\subsubsection{Doğrusal olmayan puanlama özelliklerinin tanımlanmasl}

Doğrusal olmayan özelliklere göre ineklerin 100 puan üzerinden puanlanmasında her bir özellik ile ilgili unsurlara bakılarak inekler sırasıyla süt tipi, beden kapasitesi, ayak ve bacak yapısı ile meme yapısı bakımından puanlanmış ve sınıflandırma formuna kaydedilmiştir. Ağırlık katsayıları süt tipi için \%15, beden kapasitesi için $\% 20$, ayak ve bacak yapısı için \%25 ve meme yapısı için \%40 ile çarpılıp 4 kategori için hesaplanan puanların toplanması suretiyle toplam puan hesaplanmıştır (Kumlu, 2000).

Çizelge 1. Dış görünüş özellikleri için en düşük ve en yüksek puanların anlamı, ideal puanlar, ortalamalar ve standart sapmalar

Table 1. Meaning of lowest and highest scores, ideal scores, means, standard deviations for type traits

\begin{tabular}{|c|c|c|c|c|c|c|}
\hline Özellikler & & $\begin{array}{c}\text { En düşük } \\
1\end{array}$ & $\begin{array}{c}\text { En yüksek } \\
9\end{array}$ & İdeal & $\overline{\mathrm{X}}$ & SD \\
\hline Sağrı Yüksekliği & SY & Alçak $(130 \mathrm{~cm})$ & Yüksek $(154 \mathrm{~cm})$ & 145 & 147.42 & 5.23 \\
\hline Sütçülük Özelliği & SÖ & Kaba & Narin & $7-9$ & 5.65 & 0.93 \\
\hline Göğüs Genişliği & GG & Dar & Geniş & 9 & 5.00 & 0.87 \\
\hline Beden Derinliği & $\mathrm{BD}$ & $\mathrm{S}_{1} \breve{\mathrm{g}}$ & Derin & 7 & 6.02 & 0.84 \\
\hline Sağrı Eğimi & SE & Yükselen & Alçalan & 5 & 5.49 & 1.03 \\
\hline Sağrı Genişliği & SG & Dar & Geniş & $7-9$ & 5.06 & 0.88 \\
\hline Arka Ayak açısı & AAA & Dik & Geniş & 5 & 5.37 & 1.04 \\
\hline Arka Diz Yapısı & $\mathrm{ADY}$ & Kaba & Kuru & 9 & 4.77 & 0.71 \\
\hline Tırnak Taban Yüksekliği & TTY & Alçak & Yüksek & 9 & 5.53 & 0.79 \\
\hline Arka Bacak Duruşu & $\mathrm{ABD}$ & Dişa dönük & İçe dönük & $5-9$ & 4.52 & 1.05 \\
\hline Meme Derinliği & MD & Düşük & Yüksek & 5 & 5.07 & 1.19 \\
\hline Ön Meme Bağlantısı & ÖMB & Zayıf & Güçlü & $7-9$ & 4.63 & 1.03 \\
\hline Arka Meme Yüksekliği & AMY & Alçak & Yüksek & 9 & 5.27 & 1.03 \\
\hline Meme Merkez Bağı & MMB & Zayıf & Güçlü & 9 & 5.43 & 1.59 \\
\hline Ön Meme Başı Yerleşimi & ÖMBY & Lobun dişında & Lobun içinde & 5 & 4.39 & 0.79 \\
\hline Meme Başı Uzunluğu & MBU & Kisa & Uzun & 5 & 5.00 & 0.99 \\
\hline Toplam Puan & $\mathrm{TP}$ & 57 & 90 & $>80$ & 79.09 & 1.35 \\
\hline
\end{tabular}

Kaynak: (Duru, 2005; Bohlouli ve ark., 2015)

\subsection{Süt ve Döl Verim Özellikleri}

$\mathrm{Bu}$ çalışmada süt verim özelliği olarak 305 gün süt verimi (305-gSV), döl verim özellikleri olarak ise, buzağılama ile ilk tohumlama arası süre (BİTAS), servis periyodu (SP) ve buzağılama aralığı (BA) kullanılmıştır. Ölü doğum yapanlar, yavru atanlar ve buzağılama aralığı 310 günden az ve 650 günden fazla olanlar değerlendirmeye alınmamıştır (Kumlu ve Akman, 1999). Süt ve döl verimi ile ilgili kayıtlar bilgisayarlı sürü yönetim (afimilk) programından elde edilmiştir.

Çizelge 2. Süt ve döl verim özelliklerine ait tanımlayıcı değerler Table 2. Descriptive values of milk yield and reproductive traits

\begin{tabular}{lcccccc}
\hline & $\mathrm{N}$ & $\overline{\mathrm{X}}$ & $S_{X}$ & $S_{\bar{x}}$ & Minimum & Maksimum \\
\hline 305-GSV (kg) & 230 & 9805.09 & 1715.92 & 113.15 & 5054 & 14425 \\
BİTAS (gün) & 230 & 66.07 & 19.98 & 1.32 & 29 & 170 \\
SP (gün) & 230 & 134.07 & 72.04 & 4.75 & 40 & 320 \\
BA (gün) & 230 & 414.53 & 74.22 & 4.89 & 307 & 590 \\
\hline
\end{tabular}

305-gSV: 305 gün süt verimi, BİTAS: Buzağılama ile ilk tohumlama arası süre, SP: Servis periyodu, BA: Buzağılama aralığ1 $S_{X}:$ Standart sapma, $S_{\bar{x}}:$ Standart hata

\subsection{Istatistiksel Analizler}

Çalışmada, üzerinde durulan özelliklere etki eden faktörler ile tanımlayıcı istatistiklerin belirlenmesinde SPSS 17.0 paket programından yararlanılmıştır. Genetik parametrelerin tahmini için kullanılan MTDFREML programına verilerin aktarılmasında yani pedigri ve veri dosyalarının oluşturulmasında Minitap (1998) programı kullanılmıştır. Parametre ve damızlık değer tahmini ve parametreler için BLUP Hayvan Modeli'ni (Animal Model, birey modeli) esas alan MTDFREML adlı bilgisayar programından yararlanılmıştır (Boldman ve ark., 1993). 
Aşağıda doğrusal tanımlama özellikleri için kullanılan bireysel hayvan modeli matris yazılımı verilmiştir.

$\mathrm{y}=\mathrm{Xb}+\mathrm{Za}+\mathrm{e}$

Modelde, y: gözlem değerleri vektörü, b: sabit etkiler (laktasyon sırası faktörü 3 seviyeli, buzağılama mevsimi faktörü 4 seviyeli) vektörü, a: şansa bağlı genetik etkiler vektörü (damızlık değerler vektörü), $\mathrm{X}$ ve $\mathrm{Z}$ : desen matrisleri ve e: şansa bağlı hata etkileri vektörüdür.

\section{Bulgular ve Tartışma}

\subsection{Dış Görünüş Özelliklerine Ait Kalıtım Dereceleri}

$\mathrm{Bu}$ çalışmada 16 özellik ve toplam puan için ideal puanlar, ortalama ve standart sapma değerleri Çizelge 1'de verilmiştir. Doğrusal tanımlama özelliklerinden sağrı yüksekliği, beden derinliği, sağrı eğimi, arka ayak açısı, meme derinliği ve meme başı uzunluğu puanları ideal ve ideale yakın olduğu, sütçülük özelliği, göğüs genişliği, sağrı genişliği, arka diz yapısı, tırnak taban yüksekliği, arka bacak duruşu, ön meme bağlantısı, arka meme yüksekliği, meme merkez bağı ve ön meme başı yerleşimi puanlarının ise ideal puanlardan uzak olduğu görülmektedir. Toplam puan bakımından ise damızlık olarak kullanılabilir sınıfında yer almaktadır. Süt ve döl verim özelliklerine ait ortalama, standart sapma, minimum ve maksimum değerleri Çizelge 2'de özetlenmiştir. 305-gSV, BİTAS, SP ve BA'na ait ortalamalar sırasıyla $9805.09 \mathrm{~kg}, 66.07$ gün, 134.07 gün ve 414.53 gün olarak belirlenmiştir.

Sütçülük Özelliği için kalıtım derecesi 0.29 olarak hesaplanmıştır. Nitekim bu sonuç Klassen ve ark. (1992) ile Duru (2005) tarafından 0.13 ve 0.53 olarak belirlenen araştırma bulguları ile farklı bulunmasına karşın, genel olarak birçok araştırma sonucu ile uyumludur (Veerkamp ve Brotherstone, 1997; Zavadilová ve Śtípková, 2012; Zavadilová ve ark., 2014).

Çizelge 3. Dış görünüş özelliklerine ait varyans unsurları ve kalıtım derecesi

Table 3. Variance components and heritability of type traits

\begin{tabular}{lccccccc}
\hline & $\mathrm{V}_{\mathrm{a}}$ & $\mathrm{V}_{\mathrm{e}}$ & $\mathrm{V}_{\mathrm{p}}$ & $h^{2}$ & $S_{\bar{x}}$ & $e^{2}$ & $S_{\bar{x}}$ \\
\hline Sağrı Yüksekliği & 9.110 & 17.654 & 26.764 & 0.34 & 0.256 & 0.660 & 0.256 \\
Sütçülük Özelliği & 0.237 & 0.583 & 0.821 & 0.29 & 0.250 & 0.710 & 0.250 \\
Göğüs Genişliği & 0.083 & 0.632 & 0.715 & 0.12 & 0.179 & 0.880 & 0.179 \\
Beden Derinliği & 0.145 & 0.411 & 0.556 & 0.26 & 0.189 & 0.740 & 0.186 \\
Sağrı Ĕ̆imi & 0.163 & 0.877 & 1.040 & 0.16 & 0.188 & 0.840 & 0.188 \\
Sağrı Genişliği & 0.181 & 0.492 & 0.673 & 0.27 & 0.272 & 0.730 & 0.271 \\
Arka Ayak Açısı & 0.106 & 0.806 & 0.912 & 0.12 & 0.191 & 0.880 & 0.192 \\
Arka Diz Yapısı & 0.037 & 0.466 & 0.503 & 0.07 & 0.142 & 0.930 & 0.142 \\
Tırnak Taban Yüksekliği & 0.039 & 0.509 & 0.547 & 0.07 & 0.199 & 0.930 & 0.199 \\
Arka Bacak Duruşu & 0.189 & 0.963 & 1.152 & 0.16 & 0.289 & 0.840 & 0.289 \\
Meme Derinliği & 0.302 & 0.377 & 0.679 & 0.44 & 0.275 & 0.480 & 0.275 \\
Ön Meme Bağlantısı & 0.483 & 0.699 & 1.182 & 0.41 & 0.259 & 0.590 & 0.259 \\
Arka Meme Yüksekliği & 0.306 & 0.678 & 0.983 & 0.31 & 0.243 & 0.690 & 0.241 \\
Meme Merkez Bağı & 0.767 & 1.564 & 2.331 & 0.33 & 0.225 & 0.670 & 0.225 \\
Ön Meme Başı Yerleşimi & 0.239 & 0.380 & 0.618 & 0.39 & 0.275 & 0.610 & 0.271 \\
Meme Başı Uzunluğu & 0.079 & 0.904 & 0.984 & 0.08 & 0.199 & 0.920 & 0.197 \\
Toplam Puan & 0.630 & 1.000 & 1.630 & 0.39 & 0.133 & 0.610 & 0.244 \\
\hline V.:
\end{tabular}

$\mathrm{V}_{\mathrm{a}}$ : eklemeli genetik varyans, $\mathrm{V}_{\mathrm{e}}$ : çevre etkisinden kaynaklanan varyans, $\mathrm{V}_{\mathrm{p}}$ : fenotipik varyans, $h^{2}:$ Kalıtım derecesi, $e^{2}:$ Hatanın Etki Payı, $S_{\bar{x}}$ : Standart hata

Araştırmada beden özellikleri için 0.12 ile 0.34 arasında değişen düşük ve orta düzeyde kalıtım dereceleri belirlenmiştir (Çizelge 3). Görüldüğü üzere gögüs genişliği (0.12) ve sağrı eğimi (0.16) için düşük, beden derinliğgi (0.26), sağrı genişliği $(0.27)$ ve sağrı yüksekliği (0.34) için belirlenen kalıtım derecesi ise orta düzeyde tespit edilmiştir. Bu değerlerden hem çevresel hem de eklemeli olmayan genetik etkileri içeren kalıc1 etkilerin göğüs genişliği ve sağrı eğimi için eklemeli genetik etkilerden daha önemli olduğu, beden derinliği, sağrı genişliği ve sağrı yüksekliği üzerine ise eklemeli genlerin daha fazla etkili olduğu sonucuna varılabilir. Bu çalışmada göğüs genişliği 
ve sağrı eğimi için belirlenen kalıtım derecesi Cassandro ve ark. (2015) ile uyumlu olup, beden derinliği, sağrı genişliği ve sağrı yüksekliği için farklı bulunmuştur. Yine çalışma sonucu Türkiye'de Siyah Alaca ineklerde yapılan araştırmalarda sağrı genişliği için farklı, sağrı eğimi için benzer bulunmuştur (Duru, 2005; Çerçi, 2006).

Genel olarak göğüs genişliği ve sağrı eğimi için bu çalışma sonucu ilgili özellikler için orta düzeyde kalıtım derecesi hesaplayan çoğu araştırma sonucundan düşük, beden derinliği, sağrı genişliği ve sağrı yüksekliği için orta düzeyde kalıtım derecesi hesaplayan araştırma bulguları ile uyumludur (Pryce ve ark., 2000; DeGroot ve ark., 2002; Tapki ve Guzey, 2013; Campos ve ark., 2015).

Çizelge 3'de verildiği üzere ayak ve bacak özellikleri (arka ayak açısı, arka diz yapısı, tırnak taban yüksekliği ve arka bacak duruşu) için 0.07 ile 0.16 arasında değişen düşük düzeyde kalıtım derecesi hesaplanmıştır. Bu sonuç üzerinde durulan özellikler üzerine çevresel ve eklemeli olmayan genetik etkilerin önemli etkisinin bir sonucudur. Bir başka ifade ile yüksek düzeyde çevre etkisinden kaynaklanan varyans ile düşük düzeydeki eklemeli genetik varyans bu özellikler için belirlenen düşük kalıtım derecesinin bir sonucudur. Nitekin bu araştırma sonucu ilgili özellikler için çoğu araştırma sonuçları ile uyumludur (Duru, 2015; Çerçi, 2016; Zavadilová ve ark., 2014; Bohlouli ve ark., 2015). Ancak Susanto ve ark. (2018) tarafından tırnak taban yüksekliği ve arka bacak duruşu için 0.236 ve 0334 olarak belirlenen kalıtım derecesi bu araştırma sonuçlarından yüksektir.

Meme özelliklerinden meme başı uzunluğu (0.08) için düşük, arka meme yüksekliği (0.31), meme merkez bağ 1 (0.33) ve ön meme başı yerleşimi (0.39) için orta, ön meme bağlantısı $(0.41)$ ve meme derinliği (0.44) için ise yüksek düzeyde kalıtım derecesi tespit edilmiştir. Görüldügü üzere meme özellikleri için meme başı uzunluğu hariç genel olarak orta ve yüksek düzeyde kalıtım derecesi hesaplanmıştır (Çizelge 3). Bu sonuçlar meme başı uzunluğu hariç meme özellikleri için yapılacak genetik iyileştirmelerde genetik faktörlerin daha fazla etkili olacağının bir göstergesidir. İlgili özellikler için yapılan çalışmalarda da genel olarak orta ve yüksek düzeyde kalıtım dereceleri hesaplanmıştır (Pryce ve ark., 2000; DeGroot ve ark., 2002; Zavadilová ve Štípková, 2012; Campos ve ark., 2015). Ayrıca meme başı uzunluğu için Berry ve ark. (2004) ve Cassandro ve ark. (2015) tarafindan sirasıyla 0.14 ve 0117 olarak belirlenen çalışma sonucu bu araştırma bulgusu ile uyumludur. Farklı olarak Cassandro ve ark. (2015) meme derinliği, ön meme bağlantısı, arka meme yüksekliği, meme merkez bağı ve ön meme başı yerleşimi için 0.048 ile 0.119 arasında değişen düşük düzeyde kalıtım derecesi hesaplamışlardır. Toplam puan için 0.39 olarak hesaplanan kalıtım derecesi ise DeGroot ve ark. (2002)'nin bulgusu ile benzer olmasına karşıı birçok araştırma sonucundan yüksektir (Çerçi, 2006; Ermetin, 2007; Campos ve ark., 2015; Cassandro ve ark., 2015).

\subsection{Süt ve Döl Verim Özelliklerine Ait Kalttım Dereceleri}

Süt ve döl verim özelliklerine ait varyans unsurları ve kalıtım dereceleri Çizelge 4'te verilmiştir. Bu çalışmada 305-gSV için kalıtım derecesi 0.18 olarak hesaplanmıştır. Nitekim 305-gSV için belirlenen kalıtım derecesinin düşük-orta düzeyde olduğu söylenebilir. Bu sonuç, bu özellik için yapılacak seleksiyonların, süt verimini artırmaya yardımcı olabilecek bir genetik değişikliğin elde edilebileceği anlamı taşımaktadır. Yapılan çalışmalarda en düşük kalıtım derecesi DeGroot ve ark. (2002) tarafindan 0.13, Misztal ve ark. (1992) tarafindan ise 0.44 olarak belirlenmiş olup, diğer çalışmalarda da 305 -gSV için orta düzeyde kalıtım derecesi belirlenmiştir (Tapki ve Guzey, 2012; Campos ve ark., 2015; Sarar, 2015; Montaldo ve ark., 2017).

Çizelge 4. Süt ve döl verim özelliklerine ait varyans unsurları ve kalıtım dereceleri

Table 4. Variance componets and heritability of milk yield and reproductive traits

\begin{tabular}{lrrrrrrc} 
& \multicolumn{1}{c}{ Va } & \multicolumn{1}{c}{ Ve } & \multicolumn{1}{c}{$\mathrm{Vp}$} & $h^{2}$ & $S_{\bar{x}}$ & $e^{2}$ & $S_{\bar{x}}$ \\
\hline 305-gSV (kg) & 501014 & 2242991 & 2744005 & 0.18 & 0.012 & 0.810 & 0.087 \\
BİTAS (gün) & 0.281 & 3.439 & 3.720 & 0.08 & 0.185 & 0.910 & 0.183 \\
SP (gün) & 0.206 & 3.925 & 4.131 & 0.05 & 0.162 & 0.950 & 0.197 \\
BA (gün) & 0.734 & 4.718 & 5.452 & 0.13 & 0.178 & 0.87 & 0.174 \\
\hline
\end{tabular}

305-gSV: 305 gün süt verimi, BİTAS: Buzağılama ile ilk tohumlama arası süre, SP: Servis periyodu, BA: Buzağılama aralığı, $\mathrm{V}_{\mathrm{a}}$ : eklemeli genetik varyans, $\mathrm{V}_{\mathrm{e}}$ : çevre etkisinden kaynaklanan varyans, $\mathrm{V}_{\mathrm{p}}$ : fenotipik varyans, $h^{2}:$ Kalıtım derecesi, $e^{2}$ : Hatanın Etki Payı, $S_{\bar{x}}$ : Standart hata

Döl verim özelliklerinden SP için düşük düzeyde belirlenen kalıtım derecesi (0.05) ise birçok çalışma sonucu ile uyumlu olup (Pozveh ve ark., 2009; Zink ve ark., 2011; Almeida ve ark., 2017), Çerçi (2006) tarafindan belirlenen kalıtım derecelerinden daha düşüktür. BA için belirlenen kalıtım derecesi (0.13) konu üzerinde yapılan çalışmalarda da düşük düzeyde belirlenmiş olup, genel olarak elde edilen sonuçlar bu çalışma sonucu ile uyumludur (Sarar, 2015; González-Recio ve ark., 2016; Almeida ve ark., 2017; Montaldo ve ark., 2017). BİTAS için 0.08 düzeyinde kalıtım derecesi tespit edilmiştir. Görüldüğü üzere BA için belirlenen kalıtım derecesi SP ve BİTAS ile karşılaştırıldığında biraz yüksek olmasına karşın yine de düşük düzeydedir. Bu değerler üreme özelliklerinin büyük oranda çevresel faktörlerden etkilendiği ve bu nedenle bu özellikler için yapılacak doğrudan seleksiyonların yavaş genetik ilerleme sağlayacağının göstergesidir. Nitekim bu durum döl verim özelliklerinin doğrudan seleksiyon kriteri olarak 
kullanımının zor olacağı hipotezinini doğrulamaktadır (Almeida ve ark., 2017). Bu nedenle döl verim özelliklerinin iyileştirilmesi için bu özellikler üzerine etkili çevresel faktörlerin iyileştirilmesi yoluna gidilmelidir.

\subsection{Dış Görünüş Özellikleri ile Süt ve Döl Verim Özellikleri Arasındaki Fenotipik Korelasyonlar}

Bu çalışmada 305-gSV ile sütçülük özelliği, sağrı yüksekliği, göğüs genişliği, beden derinliği, sağr1 eğimi, sağr1 genişliği, arka ayak açısı, arka diz yapısı, tırnak taban yüksekliği ve arka bacak duruşu gibi doğrusal tanımlama özellikleri arasında -0.11 ile 0.09 arasında negatif ve pozitif yönde düşük düzeyde fenotipik korelasyonlar tespit edilmiştir. Ancak 305-gSV ile ön meme bağlantısı (-0.19), arka meme yüksekliği (0.22) ve meme merkez bağ (0.25) ile olan korelasyonlar diğer özelliklerden daha yüksek bulunmuştur (Çizelge 5). Görüldüğü üzere daha zayıf ön meme bağlantısı, daha fazla arka meme yüksekliği ve daha güçlü meme merkez bağı'na sahip olan ineklerin nispeten daha yüksek süt verimine sahip olacağı söylenebilir. Kounu üzerinde yapılan çalışmalarda 305-gSV ile en yükssek fenotipik korelasyonları Tapkı (2001) sütçülük özelliği (0.432), Short ve Lawlor (1992) sütçülük özelliği (0.29), Duru (2005) beden derinliği (0.21), arka meme yüksekliği (0.22) ve meme baş1 yerleşimi (0.24), Pantelić ve ark. (2012) meme merkez bağ (0.23), Tapki ve Guzey (2013) meme derinliği (-0.31) ve ön meme bağlantıs1 (-0.23), Campos ve ark. (2015) sütçülük özelliği (0.25) ve meme derinliği (-0.46), Wasana ve ark. (2015) ise sağrı genişliği (0.20), beden derinliği (0.21) ve meme derinliği (-0.26) arasında belirlemişlerdir. Araştırmada 305-gSV ile toplam puan arasındaki fenotipik korelasyonlar 0.24 düzeyinde hesaplanmış olup toplam puan için daha iyi damızlık vasfı taşıyan ineklerin yüksek süt verimine sahip olacağı söylenebilir.

Çizelge 5. Dış görünüş özellikleri ile süt ve döl verim özellikleri arasındaki fenotipik korelasyonlar

Table 5. Phenotypic correlations between type traits and milk yield and reproductive traits

\begin{tabular}{|c|c|c|c|c|}
\hline & 305-gSV & BİTAS & SP & BA \\
\hline Sağrı Yüksekliği & 0.02 & 0.03 & 0.07 & 0.07 \\
\hline Sütçülük Özelliği & 0.09 & 0.05 & -0.01 & 0.01 \\
\hline Göğüs Genişliği & -0.05 & 0.05 & 0.07 & 0.12 \\
\hline Beden Derinliği & 0.06 & -0.04 & 0.09 & 0.16 \\
\hline Sağr1 Eğimi & 0.04 & -0.11 & 0.01 & -0.01 \\
\hline Sağrı Genişliği & 0.03 & 0.04 & 0.05 & 0.07 \\
\hline Arka Ayak açısı & -0.11 & 0.03 & 0.10 & 0.10 \\
\hline Arka Diz Yapısı & 0.09 & -0.05 & -0.02 & 0.02 \\
\hline Tırnak Taban Yüksekliği & 0.04 & 0.02 & 0.07 & 0.08 \\
\hline Arka Bacak Duruşu & 0.13 & -0.04 & -0.25 & -0.24 \\
\hline Meme Derinliği & -0.08 & -0.01 & -0.05 & -0.06 \\
\hline Ön Meme Bağlantısı & -0.19 & 0.05 & 0.06 & 0.06 \\
\hline Arka Meme Yüksekliği & 0.22 & -0.13 & -0.06 & -0.06 \\
\hline Meme Merkez Bağı & 0.25 & -0.08 & -0.01 & 0.01 \\
\hline Ön Meme Başı Yerleşimi & -0.04 & 0.05 & 0.13 & 0.15 \\
\hline Meme Başı Uzunluğu & 0.08 & -0.01 & -0.02 & -0.07 \\
\hline Toplam Puan & 0.24 & -0.06 & -0.02 & 0.04 \\
\hline
\end{tabular}

305-gSV: 305 gün süt verimi, BITAS: Buzağılama ile ilk tohumlama arası süre, SP: Servis periyodu, BA: Buzağılama aralığı

Döl verim özelliklerinden BİTAS ile tüm doğrusal tanımlama özellikleri arasında -0.16 ile 0.05 arasında değişen düşük düzeyde fenotipik korelasyonlar tespit edilmiştir (Çizelge 5). BİTAS ile toplam puan arasındaki korelasyon ise -0.06 olarak bulunmuştur. Wall ve ark. (2005) tarafindan bu çalışma sonucu ile benzer olarak BİTAS ile sağrı eğimi, sağrı genişliği, arka meme yüksekliği ve meme merkez bağı arasında sırasıyla $-0.01,-0.02,0.03$ ve 0.03 düzeyinde fenotipik korelasyonlar tespit edilmiştir.

SP ile tüm doğrusal tanımlama özellikleri arasındaki fenotipik korelasyonlar -0.25 ile 0.13 arasında belirlenmiştir. Görülügü üzere belirlenen korelasyonlar düşük düzeydedir. Ancak SP ile en yüksek korelasyon arka bacak duruşu (-0.25) arasında hesaplanmıştır. Bu nedenle arka bacak duruşu paralel olan ineklerin SP'nun nispeten daha düşük olacağını söylemek olasıdır. SP ile toplam puan arasında ise negatif yönde ve düşük düzeyde (-0.02) korelasyon belirlenmiştir.

BA ile tüm doğrusal tanımlama özellikleri arasındaki fenotipik korelasyonlar -0.24 ile 0.16 arasında olup düşük düzeyde bulunmuştur. Bu çalışmada BA ile en yüksek korelasyonlar SP'nda olduğu gibi arka bacak duruşu (-0.24) ile belirlenmiştir. Nitekim arka bacak duruşu paralel olan ineklerin BA'nın daha düşük olacağı söylenebilir. Wall ve ark. (2005) yaptıkları çalışmalarında sağrı eğimi, sağrı genişliği, arka meme yüksekliği ve meme merkez bağ 1 arasında -0.02 ile 0.03 arasında değişen çok düşük düzeyde fenotipik korelasyonlar tespit etmişlerdir. Yine bu çalışmada BA ile toplam puan arasındaki korelasyon 0.04 olarak belirlenmiştir. 


\subsection{Dış Görünüş Özellikleri ile Süt ve Döl Verim Özellikleri arasındaki Genetik Korelasyonlar}

Bu çalışmada, Çizelge 6'da verildiği üzere 305 -gSV ile sütçülük özelliği (0.96), beden derinliği (0.81) ve arka meme yüksekliği $(0.65)$ arasında pozitif, arka ayak açısı ile negatif yönde $(-0.90)$ ve çok yüksek düzeyde genetik korelasyonlar tespit edilmiștir. Görüldüğü üzere daha narin bir sütçülük özelliğinde, daha derin beden, daha yüksek bir arka meme ile daha dik bir ayak yapısına sahip ineklerin daha yüksek süt verimine sahip olacağı söylenebilir. 305-gSV ile sağrı yüksekliği, göğüs genişliği, sağrı eğimi, sağrı genişliği ve arka diz yapısı arasında yine pozitif yönde ve 0.40 ile 0.48 arasında değişen genetik korelasyonlar tespit edilmiştir. Bu sonuçlara göre yüksek sağrılı, geniş gögüslü, alçalan ve geniş sağrılı ve daha kuru bir diz yapısına sahip ineklerin de daha yüksek süt verimine sahip olacağını söylemek olasıdır. Bu çalışmada 305 -gSV ile tırnak taban yüksekliği, arka bacak duruşu, meme derinliği, ön meme bağlantısı ve meme merkez bağı arasında pozitif yönde ve 0.03 ile 0.20 arasında, ön meme başı yerleşimi (-0.05) ve meme başı uzunluğu (-0.09) ile negatif yönde ve düşük düzeyde genetik korelasyonlar hesaplanmıştır. Bu çalışma sonucu ile benzer olarak DeGroot ve ark. (2002) tarafından 305-gSV ile sütçülük özelliği arasında 0.91 düzeyinde yüksek korelasyon belirlenirken yapılan birçok araştırmada ise yine pozitif yönde ve orta düzeyde korelasyonlar tespit edilmiştir (Short ve Lawlor, 1992; Berry ve ark., 2004; Tapki ve Guzey, 2013; González-Recio ve ark., 2016). Bu çalıșma sonucu 305-gSV ile sütçülük özelliği ve arka meme yüksekliği (Pantelić ve ark., 2012) ile beden derinliği (Short ve Lawlor, 1992; Campos ve ark., 2015) arasında negatif yönde ilişki belirleyen araştırma sonuçlarından farklı bulunmuştur. Ayrıca arka ayak açısı ile 305-gSV arasında negatif yönde ilişki tespit eden araştırma sonuçları (Pantelić ve ark., 2012; Campos ve ark., 2015; Wasana ve ark., 2015) bu çalışma sonucu ile benzerdir. Farklı olarak çoğu çalışmada (Pryce ve ark., 2000; Berry ve ark., 2004; Duru, 2005; Bohlouli ve ark., 2015) 305-gSV ile arka ayak açısı arasında pozitif yönde genetik korelasyonlar tespit edilmiştir. Ayrıca çalışmada 305-gSV ile toplam puan arasında 0.52 düzeyinde genetik korelasyon tespit edilmiştir. Bu nedenle toplam puan bakımından üstün damızlık özelliği taşıyan ineklerin daha yüksek süt verimine sahip olacağı söylenebilir.

BITTAS ile göğüs genişliği, beden derinliği, sağnı genişliği ve ön meme bağlantısı arasında 0.55 ile 0.61 arasında değişen genetik korelasyonlar tespit edilmiştir. Buradan daha dar göğüslü, daha sığ bedenli, daha dar sağrılı ve daha zayıf bir meme bağlantısına sahip ineklerin daha kısa bir BİTAS'ye sahip olacağı söylenebilir. Sağrı yüksekliği, sütçülük özelliği, beden derinliğii, sağrı eğimi, arka ayak açısı, tırnak taban yüksekliği, arka bacak duruşu, meme derinliği, arka meme yüksekliği, meme merkez bağı ve ön meme başı yerleşimi ile BİTAS arasındaki genetik korelasyonlar pozitif yönde, arka diz yapısı ve meme başı uzunluğu ile negatif yönde ve düşük düzeydedir. Bu çalışma sonucu ile benzer olarak Berry ve ark. (2004) tarafından BİTAS ile göğüs genişliği, beden derinliği, sağrı genişliği ve ön meme bağlantısı arasında sırasıyla 0.80 ve $0.68,0.74$ ve 0.40 düzeyinde genetik korelasyonlar hesaplanmıştır. Zink ve ark. (2011) tarafindan ise 305 -gSV ile göğüs genişliği ve beden derinliği arasında negatif yönde ilișki bulunmuştur. Yine bu çalışma sonucundan farklı olarak Wall ve ark. (2005) ve Zink ve ark. (2011) BİTAS ile sağrı genişliği arasında negatif yönde genetik ilişki belirlemişlerdir. BİTAS ile toplam puan arasındaki genetik korelasyon ise negatif yönde (-0.18) ve düşük düzeydedir. Ayrıca, Almeida ve ark. (2017) tarafindan BİTAS ile toplam puan arasında negatif yönde (-0.52) belirlenen genetik korelasyon bu çalışma sonucu ile benzerdir.

Çalışmada SP ile sağrı yüksekliği, sütçülük özelliği, beden derinliği, sağrı eğimi, sağrı genişliği, arka ayak açısı, arka diz yapısı, tırnak taban yüksekliği, arka bacak duruşu, meme derinliği, arka meme yüksekliği, meme merkez bağı ve meme başı uzunluğu ile 0.04 ile 0.22 arasında ve pozitif yönde, göğüs genişliği, ön meme bağlantısı ve ön meme başı yerleşimi arasında ise 0.03 ile -0.20 arasında değişen negatif yönde ve düşük düzeyde genetik korelasyonlar tespit edilmiştir. Pozveh ve ark. (2009) tarafından yapılan araştırmada ise SP ile sütçülük özelliği, beden derinliği, arka bacak duruşu ve arka meme yüksekliği ile pozitif yönde ve oldukça düşük düzeyde genetik korelasyonlar tespit edilmiştir. Bu çalışma sonucuna benzer olarak, Zink ve ark. (2011) tarafından SP ile sağrı yüksekliği, sütçülük özelliği, beden derinliği, sağrı eğimi, sağrı genişliği, arka diz yapısı, tırnak taban yüksekliği ve arka bacak duruşu arasında pozitif yönde ilişkiler belirlenmiştir. SP ile toplam puan arasındaki genetik korelasyon ise pozitif (0.07) ve düşük düzeyde bulunmuştur.

$\mathrm{Bu}$ çalışmada BA ile beden derinliği (0.41) arasında orta düzeyde, sağrı yüksekliği, sütçülük özelliği, göğüs genişliği, arka ayak açısı, tırnak taban yüksekliği, arka bacak duruşu, meme derinliğĭi, ön meme bağlantısı, arka meme yüksekliği ve meme merkez bağı arasında 0.08 ile 0.29 arasında değişen düşük düzeyde ve pozitif yönde genetik korelasyonlar tespit edilirken, sağrı eğimi, sağrı genişliği, arka diz yapısı, ön meme başı yerleşimi ve meme başı uzunluğu ile -0.09 ile -0.33 arasında negatif yönde ve düşük-orta düzeyde genetik korelasyonlar hesaplanmıştır. 
Çizelge 6. Dış görünüş özellikleri ile süt ve döl verim özellikleri arasındaki genetik korelasyonlar

Table 5. Genotypic correlations between type traits and milk yield and reproductive traits

\begin{tabular}{|c|c|c|c|c|}
\hline & $305-\mathrm{gSV}$ & BITTAS & SP & BA \\
\hline Sağrı Yüksekliği & 0.47 & 0.11 & 0.09 & 0.17 \\
\hline Sütçülük Özelliği & 0.96 & 0.23 & 0.06 & 0.29 \\
\hline Göğüs Genişliği & 0.41 & 0.59 & -0.03 & 0.22 \\
\hline Beden Derinliği & 0.81 & 0.55 & 0.17 & 0.41 \\
\hline Sağr1 Eğimi & 0.51 & 0.10 & 0.04 & -0.16 \\
\hline Sağrı Genişliği & 0.48 & 0.61 & 0.21 & -0.09 \\
\hline Arka Ayak açısı & -0.90 & 0.30 & 0.07 & 0.23 \\
\hline Arka Diz Yapıs1 & 0.40 & -0.03 & 0.13 & -0.27 \\
\hline Tırnak Taban Yüksekliği & 0.05 & 0.13 & 0.08 & 0.18 \\
\hline Arka Bacak Duruşu & 0.03 & 0.15 & 0.19 & 0.20 \\
\hline Meme Derinliği & 0.04 & 0.06 & 0.05 & 0.11 \\
\hline Ön Meme Bağlantısı & 0.20 & 0.56 & -0.14 & 0.08 \\
\hline Arka Meme Yüksekliği & 0.65 & 0.17 & 0.22 & 0.15 \\
\hline Meme Merkez Bağı & 0.16 & 0.12 & 0.18 & 0.23 \\
\hline Ön Meme Başı Yerleşimi & -0.05 & 0.20 & -0.20 & -0.13 \\
\hline Meme Başı Uzunluğu & -0.09 & -0.15 & 0.08 & -0.33 \\
\hline Toplam Puan & 0.52 & -0.18 & 0.07 & 0.08 \\
\hline
\end{tabular}

305-gSV: 305 gün süt verimi, BİTAS: Buzağılama ile ilk tohumlama arası süre, SP: Servis periyodu, BA: Buzağılama aralı̆̆

Bu çalışma sonucu ile benzer olarak Pryce ve ark. (2000) BA ile sütçülük özelliği, göğüs genişliği ve beden derinliği arasında 0.26 ile 0.33 arasında değişen genetik korelasyonlar tespit etmişlerdir. Makgahlela ve ark. (2009) yaptıkları çalışmada BA ile sağrı yüksekliği, sütçülük özelliği ve beden derinliği arasında sırasıyla $0.31,0.32$ ve 0.51 düzeyinde genetik korelasyonlar belirlemişlerdir. Bu çalışma sonucundan farklı olarak Almeida ve ark. (2017) sağrı yüksekliği, göğüs genişliği ve beden derinliği ile BA arasında negatif yönde korelasyonlar tespit etmiş̧lerdir. Çalışmada BA ile toplam puan arasında 0.08 düzeyinde düşük düzeyde genetik korelasyon tespit edilmiştir. Farklı olarak Almeida ve ark. (2017) tarafindan BA ile toplam puan arasında negatif yönde (-0.54) genetik korelasyon belirlenmiştir. Bu çalışma ile bazı araştırma sonuçlarında farklı olmasında, kullanılan farklı puanlama yöntemleri ve istatistik modeller ile çalışmalarda kullanılan hayvan sayılarının farklı olması, puanlama yapan kişilerin bilgi ve deneyimi ile çalışmanın farklı yıllarda ve sürü yönetim uygulamaları arasındaki farklılıkların önemli etkisinin olduğu düşünülmektedir (Van Dorp ve ark., 1998).

\section{Sonuç}

Araştırmada sağrı yüksekliği, sütçülük özelliği, beden derinliği, sağrı genişliği, arka meme yüksekliği, meme merkez bağı, ön meme başı yerleşimi, meme derinliği ve toplam puan için orta düzeyde, göğüs genişliği, sağrı eğimi, arka ayak açısı, arka diz yapısı, tırnak taban yüksekliği, arka bacak duruşu ve meme başı uzunluğu için düşük düzeyde kalıtım dereceleri hesaplanmıştır. $305-\mathrm{gSV}$ için düşük-orta, döl verim özelliklerinden BİTAS, SP ve BA için düşük düzeyde kalıtım dereceleri belirlenmiştir. $\mathrm{Bu}$ nedenle 305 -gSV ile ilgili doğrusal puanlama özelliklerinden orta-yüksek düzeyde kalıtım derecesine sahip özelliklerin seleksiyon kriteri kullanılabileceğini söylemek olasıdır. Ancak döl verim özelliklerinin iyileştirilmesi amacıyla bu özellikler üzerine etkili çevresel faktörlerin iyileştirilmesi yoluna gidilmelidir.

D1ş görünüş özellikleri ile en yüksek genetik korelasyonlar 305-gSV arasında tespit edilmiştir. Döl verim özellikleri ile dış görünüş özellikleri arasındaki genetik korelasyonlar ise düşük-orta düzeyde belirlenmiştir. Bu nedenle süt ve döl verim özellikleri ile orta ve yüksek düzeyde korelasyona sahip dış görünüş özelliklerden herhangi birine dayanan seleksiyonlarla süt ve döl veriminde iyileşme sağlanabileceği söylenebilir. Elde edilen sonuçlar, Siyah Alaca ineklerde bu özelliklerin süt ve döl verim özelliklerinin iyileştirilmesinde dolaylı seleksiyon kriteri olarak kullanılabileceğini göstermiştir.

\section{Teșekkür}

$\mathrm{Bu}$ çalışma Ramazan Erkmen tarafından yapılan yüksek lisans tezinden özetlenmiştir. Ayrıca bu çalışmadaki katkılarından dolayı Doç. Dr. Aziz Şahin ve Doç. Dr. Serdar Duru’ya teşekkürlerimizi sunarız. 


\section{Kaynaklar}

Almeida, T.P., Kern, E.L., Daltro, D.D.S., Braccini Neto, J., McManus, C., Thaler Neto, A., Cobuci, J.A., 2017. Genetic associations between reproductive and linear-type traits of Holstein cows in Brazil. Revista Brasileira de Zootecnia, 46(2): 91-98. https://doi.org/10.1590/S1806-92902017000200002

Anonymous, 2018. ICAR Guidelines for conformation recording of dairy cattle, beef cattle, dual purpose cattle and dairy goats. The Global Standard for Livestock Data. Section 5-Conformation Recording. Vesion June 2018, ICAR.

Berry, D.P., Buckley, F., Dillon, P., Evans R.D., Veerkamp, R.F., 2004. Genetic relationship among linear type traits, milk yield, body weight, fertility and somatic cell count in primiparous dairy cows. Iris Journal of Agricultural and Food Research, 43: 161-176.

Bohlouli, M., Alijani, S., Varposhti, M.R., 2015. Genetic relationships among linear type traits and milk production traits of Holstein dairy cattle. Annals of Animal Science, 15(4): 903-917. https://doi.org/10.1515/aoas2015-0053

Boldman, K.G., Kriese, L.A., Van Vleck, L.D., Van Tassell, C.P., Kachman, S.D., 1993. A Manual for Use of MTDFREML. A Set of programs to obtain estimates of variances and covariances [DRAFT]. U.S. Department of Agriculture, Agricultural Research Service.

Campos, R.V., Cobuci, J.A., Kern, E.L., Costa, C.N., McManus, C.M., 2015. Genetic parameters for linear type traits and milk, fat, and protein production in Holstein cows in Brazil. Asian-Australasian Journal of Animal Sciences, 28(4): 476-484. https://10.5713/ajas.14.0288

Cassandro, M., Battagin, M., Penasa, M., Demarchi, M., 2015. Short communication: Genetic relationships of milk coagulation properties with body condition score and linear type traits in Holstein-Friesian cows. Journal of Dairy Science, 98: 685-691. https://10.3168/jds.2014-8153

Çerçi, S., 2006. Aydın ilinde bazı işletmelerde yetiştirilen Siyah-Alaca süt sığırlarının dış görünüşlerine göre sınıflandırılması. Yüksek Lisan Tezi. Adnan Menderes Üniversitesi Fen Bilimleri Enstitüsü, 62 sayfa, Aydın.

DeGroot, B.J., Keown, J.F., Van Vleck, L.D., Marotz, E.L., 2002. Genetic parameters and responses of linear type, yield traits, and somatic cell scores to divergent selection for predicted transmitting ability for type in Holsteins. Journal of Dairy Science, 85(6): 1578-1585. https://10.3168/jds.S0022-0302(02)74227-6

Duru, S., 2005. Siyah Alaca sığırlarda dış görünüş özelliklerine ait parametre ve damızlık değer tahmini. Doktora Tezi. Uludağ Üniversitesi Fen Bilimleri Enstitüsü Zootekni Anabilim Dalı, 134 sayfa, Bursa.

Ermetin, O., 2007, Konya İlinde soykütüğü çalışmaları yapılan işletmelerde yetiştirilen Siyah Alaca ineklerin bazı fizyolojik ve morfolojik özellikleri üzerine araştırmalar. Doktora Tezi. Selçuk Üniversitesi, Fen Bilimleri Enstitüsü Zootekni Anabilim Dalı, 96 sayfa, Konya.

González-Recio, O., Haile-Mariam, M., Pryce, J.E., 2016. Improving the reliability of female fertility breeding values using type and milk yield traits that predict energy status in Australian Holstein cattle. Journal of Dairy Science, 99(1): 493-504. https://doi.org/10.3168/jds.2015-10001

Klassen, D.J., Monardes, H.G., Jairath, L., Cue, R.I., Hayes, F., 1992. Genetic correlations between lifetime production and linearized type in Canadian Holsteins. Journal of Dairy Science, 75(8): 2272-2282. https://doi.org/10.3168/jds.S0022-0302(92)77988-0

Kumlu, S., 2000, Damızlık ve kasaplık sığır yetiştirme. Türkiye Damızlık Sığır Yetiştiricileri Merkez Birliği Yayınları Yayın No, 3, Ankara.

Kumlu, S., Akman, N., 1999. Türkiye damızlık Siyah Alaca sürülerinde süt ve döl verimi. Lalahan Hayvancılık Arastırma Enstitüsü Dergisi, 39(1): 1-15.

Madrid Gaviria, S., Echeverri Zuluaga, J.J., 2014. Association between conformation traits and reproductive traits in Holstein cows in the department of Antioquia-Colombia. Revista Facultad Nacional de Agronomía Medellín, 67(2): 7321-7329. https://doi.org/10.15446/RFNAM.V67N2.44174

Makgahlela, M.L., Mostert, B.E., Banga, C.B., 2009. Genetic relationships between calving interval and linear type traits in South African Holstein and Jersey cattle. South African Journal of Animal Science, 39(1): 90-92. https://doi.org/10.4314/sajas.v39i1.61221

Minitab, 1998. Minitab Reference Manuel, Release 12, For Windows Minitab Inc.

Misztal, I., Lawlor, T.J., Short, T.H., VanRaden, P.M., 1992. Multiple-trait estimation of variance components of yield and type traits using an animal model. Journal of Dairy Science, 75(2): 544-551. https://doi.org/10.3168/jds.S0022-0302(92)77791-1

Montaldo, H., Trejo, C., Lizana, C., 2017. Genetic parameters for milk yield and reproduction traits in the Chilean Dairy Overo Colorado cattle breed. Ciencia e Investigación Agraria, 44(1): 24-34. https://doi.org/10.7764/rcia.v44i1.1562

Pantelić, V., Nikšić, D., Ostojić-Andrić, D., Novaković, Z., Ružić-Muslić, D., Maksimović, N., Lazarević, M., 2012. Phenotypic and genetic correlations of milk and type traits of Holstein-Friesian bull dams. Biotechnology in Animal Husbandry, 28(1): 1-10. https://doi.org/10.2298/BAH1201001P 
Pozveh, S.T., Shadparvar, A.A., Shahrbabak, M.M., Taromsari, M.D., 2009. Genetic analysis of reproduction traits and their relationship with conformation traits in Holstein cows. Livestock Science, 125(1): 84-87. https://doi.org/10.1016/j.livsci.2009.02.015

Pryce, J.E., Coffey, M.P., Brotherstone, S., 2000. The genetic relationship between calving interval, body condition score and linear type and management traits in registered Holsteins. Journal of Dairy Science, 83(11): 2664-2671. https://doi.org/10.3168/jds.S0022-0302(00)75160-5

Sarar, A.D., 2015. Siyah Alaca ineklerde süt ve döl verimine ait bazı fenotipik ve genotipik parametre tahminleri üzerine bir araştırma. Yüksek Lisans Tezi. Mustafa Kemal Üniversitesi Fen Bilimleri Enstitüsü, 60 sayfa, Hatay.

Short, T.H., Lawlor, T.J., 1992. Genetic parameters of conformation traits, milk yield, and herd life in Holsteins. Journal of Dairy Science, 75(7): 1987-1998. https://doi.org/10.3168/jds.S0022-0302(92)77958-2

Susanto, A., Nurgiartiningsih, V.M.A., Hakim, L., 2018. (Co) variance components and genetics parameter estimation for linear traits in Holstein cattle in Indonesia, traits related to foot/leg and udder. Archives Animal Breeding, 61(4): 491-496. https://doi.org/10.5194/aab-61-491-2018

Tapkı, İ., 2001. Siyah Alaca sığırlarda bazı meme ölçüleri ve form özellikleri ile süt verimi arasındaki ilişki. Doktora Tezi. Mustafa Kemal Üniversitesi Fen Bilimleri Enstitüsü Zootekni Anabilim Dalı, 92 Sayfa, Antakya.

Tapki, İ., Guzey, Y.Z., 2013. Genetic and phenotypic correlations between linear type traits and milk production yields of Turkish Holstein dairy cows. Greener Journal of Agricultural Sciences, 3(11): 755-761.

TÜİK, 2021. Türkiye İstatistik Kurumu. www.tuik.gov.tr, (Erişim tarihi: 15.03.2021).

Van Dorp, T.E., Dekkers, J.C.M., Martin, S.W., Noordhuizen, J.P.T.M., 1998. Genetic parameters of health disorders, and relationships with 305-day milk yield and conformation traits of registered Holstein cows. Journal of Dairy Science, 81(8): 2264-2270. https://doi.org/10.3168/jds.S0022-0302(98)75806-0

Veerkamp, R.F., Brotherstone, S., 1997. Genetic correlations between linear type traits, food intake, live weight and condition score in Holstein Friesian dairy cattle. Animal Science, 64(3): 385-392. https://doi.org/10.1017/S1357729800015976

Wall, E., White, I.M.S., Coffey, M.P., Brotherstone, S., 2005. The relationship between fertility, rump angle, and selected type information in Holstein-Friesian cows. Journal of Dairy Science, 88(4): 1521-1528. https://doi.org/10.3168/jds.S0022-0302(05)72821-6

Wasana, N., Cho, G., Park, S., Kim, S., Choi, J., Park, B., Do, C., 2015. Genetic relationship of productive life, production and type traits of Korean Holsteins at early lactations. Asian-Australasian Journal of Animal Sciences, 28(9): 1259-1265. https://doi.org/10.5713/ajas.15.0034

Yaylak, E., Akbaş, Y., 2004. Siyah Alaca ineklerde doğrusal tanımlama özellikleri. 4. Ulusal Zootekni Bilim Kongresi, 75-79, 01-03 Eylül, Isparta.

Zavadilová, L., Přibyl, J., Vostrý, L., Bauer, J., 2014. Single-step genomic evaluation for linear type traits of Holstein cows in Czech Republic. Animal Science Papers and Reports, 32(3): 201-208.

Zavadilová, L., Štípková, M., 2012. Genetic correlations between longevity and conformation traits in the Czech Holstein population. Czech Journal of Animal Science, 57(3): 125-136. https://doi.org/10.17221/5566-CJAS

Zink, V., Štípková, M., Lassen, J., 2011. Genetic parameters for female fertility, locomotion, body condition score, and linear type traits in Czech Holstein cattle. Journal of Dairy Science, 94(10): 5176-5182. https://doi.org/10.3168/jds.2010-3644. 